Mobility as a contradictory resource: peripatetic Qur'anic students in Kano, Nigeria

Hannah Hoechner

Department of International Development, University of Oxford, Oxford, United Kingdom

3 Mansfield Road, Oxford OX1 3TB, United Kingdom, hannah.hoechner@posteo.de

Final version published in: Children's Geographies, 13(1): 59-72

Word count: 8,081 


\title{
Mobility as a contradictory resource: peripatetic Qur'anic students in Kano, Nigeria
}

\begin{abstract}
Mobility is a powerful resource young people can draw on to improve their lives, but it can also entail risks. This paper explores how mobility becomes a contradictory resource for peripatetic Qur'anic students (almajirai) in Kano State in northern Nigeria. Moving to urban areas allows the young almajirai to escape difficult conditions and to access educational and income opportunities absent at their rural homes. It makes it possible for them to adopt self-conceptions as migrants in search of sacred knowledge who were once widely respected. However, economic decline has made survival in the city more difficult. Lacking the economic and cultural resources to participate in displays of status, and without social superiors to speak for them, the almajirai feel they have become fair game for those searching for scapegoats.
\end{abstract}

Keywords: Qur'anic education, madrasa, almajirai, Nigeria, mobility, education

\section{Introduction}

\subsection{Mobility as a contradictory resource}

A 'new mobilities paradigm' or 'mobility turn' within the social sciences has been advocated to capture the fact that today '[a]ll the world seems to be on the move' (Sheller and Urry 2006, 207). But '[p]eople and things have always moved and mobility did not start in the twenty-first century' (Cresswell 2010, 555). The emerging body of literature on mobilities, new or otherwise, has however sharpened our understanding of people's movements in important ways. It has been argued for instance that not everyone has an equal relationship to mobility (Hannam, Sheller, and Urry 2006, 3) and that 'vast inequalities characterize not only the freedom to move but also the distribution of gains from movement' (UNDP 2009, 10).

A growing body of literature engages with the role mobility plays in the lives of young people, including how their movement in physical space relates to opportunities for social mobility (e.g. Gough 2008; Hansen 2005). It has been shown that for young people, geographical mobility matters as a potential asset to complete youth transitions successfully. It may allow them to tap new opportunities in terms of education, income, or experience (e.g. Crivello 2009; Porter et al. 2013; Punch 2007). But young people may also 'find themselves moving around with little reward' (Langevang and Gough 2009, 753), and they may encounter not merely new chances, but also new risks.

How young migrants, as strangers and newcomers, deal with assaults on their dignity and (re-) construct their identities in the often hostile environments of their new 'homes' has been documented amongst others for young refugees (e.g. Adams 2009; Mann 2012). Several authors describe how street children navigate the various exclusions they experience (e.g. Beazley 2003; van Blerk 2005). It is to this emerging literature on the struggles for dignity and (self-) respect of young people presumably 'out of place' that this paper adds.

Often, stark socioeconomic inequalities between regions and households shape young migrants' trajectories, for example when rural children and youths move to urban areas to work as domestics (e.g. Jacquemin 2004; Thorsen 2012). This paper asks how mobility becomes a contradictory resource for young migrants in a context where inequalities are pervasive. The stigma attached to poverty may lead poor young migrants to embrace discourses about themselves and the reasons for their migration that belie the role of structural 
factors. The young peripatetic Qur'anic students (almajirai, sg.: almajiri) that this paper is about, upon coming to Kano city in Nigeria's Muslim north, embrace self-conceptions as devoted searchers for sacred knowledge to counter the denigration and scorn they experience in the urban middle-class neighbourhoods of their schools. Such self-conceptions downplay the role poverty plays for rural families' decisions to enrol children as almajirai. It is important to think through the workings of discourses that stigmatise poor migrants, as these discourses may develop a dynamic of their own, and constrain the room available to debate the structural causes of poverty.

The next section introduces the almajirai, and the methods used to collect the data. Secondly, I trace how changes in the local political economy during the past century relegated the almajiri system - once a reliable preparation for successful adult life - to the economic, social and political margins. Simultaneously, viable 'modern' educational avenues were not opened up for poor rural communities. In an increasingly individualistic society, the almajirai today are mostly discussed in terms of personal failure. Parental neglect, ignorance and backwardness are keywords in a discourse that pathologises the almajirai's mobility and ultimately blames the poor for their own squalor.

The final section investigates the role of mobility in the lives of the almajirai. By moving to urban areas, they can escape difficult conditions and access educational and income opportunities absent at home. Also, it becomes possible for them to adopt selfconceptions as migrants in search of sacred knowledge. Once, migrant scholars were highly regarded. Yet, economic decline has made survival in the city more difficult and today, the almajirai struggle for respect. They lack the economic and cultural resources to participate in displays of status, and don't have social superiors to speak for them. Lingering at the bottom of the status hierarchy, the almajirai feel that they have become fair game for those searching for scapegoats.

\subsection{Who are the almajirai?}

The almajirai are boys and young men from primary-school age to their early twenties who are enrolled in 'residential colleges' beyond the state's purview and regulatory interventions. Many schools lack physical infrastructure beyond a canopied forecourt where the teaching takes place, compelling their students to cohabit other spaces like mosques or neighbours' entrance halls (soro). The almajirai learn to read, write, and recite the Holy Qur'an. Modern/secular or Islamic subjects other than the Qur'an do not form part of their curriculum. During the lesson-free time, the almajirai earn their livelihood. In rural areas, they collect fodder and firewood or work as farmhands. In urban areas, older students wash clothes, carry loads and engage in petty trade or handicrafts. Younger students are employed as household helps, or beg for food and money on the streets, which makes them a highly visible feature of the urban landscape. The perception is that formerly almajirai lived mainly in remote rural locales, but that today they increasingly populate the urban centres of the region.

The traditional Qur'anic school system is widespread in Muslim West Africa and used mostly by poor rural families. Such families often have few alternative educational choices as the modern schooling accessible to them tends to be both poor in quality and financially burdensome. In the almajiri system, children are handed over to the teacher (malam), who receives no salary but lives off the support given by the local community, the alms received in exchange for his spiritual services, the contributions of his students and supplementary income-generating activities. Most teachers are themselves products of the almajiri system. While many students return home at least once a year (for the major holidays or to help their parents farm), others do not see their parents for years. Some teachers migrate with their schools following seasonal agricultural patterns. 
In Nigeria, the almajirai have become the subject of much public concern in the context of increased attempts to achieve universal primary education (e.g. UBEC 2010). The push by Islamic reform movements for the formalisation of religious learning has intensified struggles over the legitimacy of different avenues to sacred knowledge. The current spate of violence related to the Boko Haram Islamist insurgency has exacerbated anxieties about Islamic radicalisation and militancy. The Muslim militant group developed at the beginning of the century in Borno State in north-eastern Nigeria out of the following of the radical preacher Shaikh Muhammad Yusuf. Since the police crushed an uprising of the sect in 2009, assassinating its leader and killing some 700 presumed followers, violence has been spiralling out of control with almost daily bombings and drive-by shootings especially in the north-east of the country.

Many have jumped to the conclusion that the Islamist sect finds easy recruits in traditional Qur'anic schools (e.g. Bagaji et al. 2012). Nobel laureate Wole Soyinka (2012) declared in an article in the Newsweek Magazine about Boko Haram that the "butchers of Nigeria" have "been deliberately bred... in madrassas and are generally known as the almajiris. From knives and machetes, bows and poisoned arrows they have graduated to AK$47 \mathrm{~s}$, homemade bombs, and explosive-packed vehicles." Other authors have declared the almajirai's deprived living conditions responsible for violence (e.g. Ogunrotifa 2013; Onuoha 2011). Almajirai may well be, and probably are, amongst the followers of Boko Haram. But there is no systematic evidence to support such assertions. What empirical evidence exists refutes the "simplistic application of economic deprivation theory" ("The Popular Discourses of Salafi Radicalism” 2012, 118).

Enrolment in Qur'anic schools all over Nigeria is estimated to exceed 9.5 million, with more than 8.5 million in the northern part of the country (UBEC 2010). How many of these students are almajirai is, however, subject to speculation, as the existing statistics do not differentiate between day-students (who stay with their parents, potentially attend modern school in addition to Qur'anic school, and include females) and 'boarding' students. Over $80 \%$ of all children and youths aged 6-21 years in Kano State are estimated to attend some form of Islamic education either in addition to attendance in a secular school, or as their only educational experience. Qur'anic 'boarding' schools exist alongside Qur'anic day-schools and follow largely the same curriculum. Modernised Islamiyya schools teach not only the Quran, but also other Islamic and in some instances secular subjects. The most reliable estimate for Kano suggests that some 300,000 boys and young men - more than an eighth of all 6-21-year olds - live as almajirai in that state (Ministry of Education 2008).

\subsection{Methods and data}

This paper builds on 13 months of fieldwork carried out in Kano State in northern Nigeria between 2009 and 2011. My fieldwork included four months in Albasu, a small rural town in Albasu Local Government Area (LGA) in the east of Kano State. Albasu, largely dependent on agriculture, is amongst the poorest areas in Kano State. For the remaining nine months, I lived at Sabuwar Kofa within Kano's Old City. I collected data in the form of fieldwork observations, semi-structured interviews, group conversations and casual interactions with almajirai, their parents, caregivers, and teachers as well as former almajirai. To gauge in what environment the almajirai find themselves, I collected data on discourses about them from media records (national and international English-language news, and internet sources including blogs and online forums), official narratives, institutional publications (from local and international organisations working with children), local academic production, and my field notes of conversations and phrases I overheard.

In addition, I draw on data from the production process of a participatory documentary film/docu-drama, which I organised during my research about the perspectives of almajirai 
on their lives and the challenges they face. This includes stories narrated or written down during the script writing process, as well as discussions about the way they would like to see their lives and identities represented on screen. The nine participating youths were aged between 15 and 20 years, and came from three different Qur'anic schools in which I had previously taught English. Some were selected by their teachers to participate, others participated because they were the oldest students in their school and therefore the 'natural' choice. Finally, I invited youths to participate whom I had known and worked with since my first visit in Nigeria and whom I was therefore particularly close to. Mindful that such sampling would to some extent limit the generalisability of my findings, I felt it was important for participants to be relatively self-confident and outspoken and of roughly similar age to ensure a good and balanced working atmosphere. Also, to make sure that no problems would arise for the almajirai in their schools, their teachers' consent to their participation in the project was essential.

For other parts of my research, it was easier to include almajirai who were younger or less self-confident than the youths participating in the film project. My research includes discussions of the photographs that young almajirai took with disposable cameras, and 'radio interviews' they conducted amongst each other with my tape recorder. Being able to take the recorder with them to conduct their interviews outside the purview of adults put them at ease, and the playful form encouraged otherwise timid children to speak out.

The next section discusses the context of the almajiri system past and present. It traces the decline of this once highly reputed educational institution to the economic, social and political margins, and takes stock of the - overwhelmingly negative - discourses that circulate about it today in Nigeria.

\section{Context of the almajiri system}

\subsection{Historical decline of a once prestigious institution}

Since the inception of Islam in what is today northern Nigeria, the religious knowledge possessed by 'traditional' Islamic scholars has been a political asset, as its Muslim rulers, by submitting to the restraints of a written code, exposed themselves to the checks of intellectuals educated in that code (Last 1993). The introduction of modern education by the British, who conquered what is today northern Nigeria at the beginning of the twentieth century, gradually undermined the religious scholars' 'monopoly over literacy' and thus their access to prestige, positions, and resources (Paden 1973). Upon independence in 1960, the first generation of modern-educated Muslims inherited power from the British (Umar 2001).

Socioeconomic change added momentum to the political transformation. Since the 1970s the income of students and teachers declined as more affluent Muslims increasingly ceased to support the almajiri system through alms and accommodation, and as those segments of society still endorsing it were hard hit by the economic downturn in the aftermath of the oil boom of the 1970s and by structural adjustment which began in 1986 (Ya'u 2000). New capital-intensive innovations such as modern cement rather than labour-intensive mudconstruction undermined the almajirai's traditional income generating activities. The push of the northern Muslim elites in the late 1970s and 1980s to extend modern education to larger parts of the population increased competition for jobs in the urban economy (Lubeck 1985). Meanwhile, those sources of income that are the preserve of 'traditional' religious scholars commissioned prayers and potions to strengthen one's charisma for example (see Last 1988) - while providing a profitable livelihood to some, can't sustain the bulk of the almajirai, and particularly not those only beginning to acquire the requisite knowledge. The establishment of 
a modern system of Islamic education (Islamiyya schools) over the second half of the twentieth century marginalised the almajiri system further.

\subsection{Poverty, inequality and shame}

It is widely acknowledged today that for people's wellbeing it is not merely absolute but also relative deprivation that matters, for it indexes experiences of marginality and exclusion. Katz writes about her field site in rural Sudan that in the wake of its incorporation into the capitalist global economy 'greater awareness of what is to be had not only increased desire, but made not having more apparent and painful than before' (2004, 227). In Nigeria, income inequality has risen dramatically since the beginning of structural adjustment in 1986, especially in the North West. Relative poverty ${ }^{i}$ soared from $27 \%$ in 1980 to $54 \%$ in 2004 (Aigbokhan 2008, 11-14). Economic change entailed the individualisation of society, and an increasing commodification of social relationships.

As economic restructuring accentuated income inequalities and impoverished large parts of the population, the landscape of religious legitimacy in Nigeria was reconfigured. In both Christianity and Islam, new religious movements emerged that provided the ethic to match the new individualistic and acquisitive economic spirit. In Christianity, Pentecostalism introduced the so-called 'gospel of prosperity'. According to Ibrahim and Ehrhardt, it 'reverses the anti-materialism associated with the early Church and justifies, and indeed, legitimises the acquisition of material wealth. In this context, it has been a major ideologue for liberal economic thinking and the promotion of capitalism' (2012, 7; cf. Freeman 2012).

Amongst Muslims, reformist movements - most prominently epitomised by the 'Society for the Removal of Innovation and Reestablishment of the Sunna' commonly referred to as Izala (see, for example, Kane 2003; Loimeier 1997) - garner increasing support in the formerly Sufi dominated region. Kane writes that Izala appealed to the 'nouveaux riches' brought forth by the oil boom, who sensed that 'some traditional values and institutions hampered their economic goals and curtailed their autonomy.' Religious reformism allowed them to eschew 'costly traditional practices of wealth redistribution' (2003, 237). The next section explores how such religious repositionings reverberate in discussions about the almajirai.

\subsection{Discourses surrounding almajirai}

The sight of scruffy-looking children with begging bowls is likely to cause discomfort to wealthy Muslims, who are aware that Islamically the umma (Muslim community) is collectively responsible for its poor members. Many northern/Hausa Muslims consider the almajirai's practice of begging and their apparent destitution a 'weak spot' of the umma, making it vulnerable to criticism by southerners/Christians (e.g. Tilde 2009). Yet the embarrassment that the almajiri system causes is not due only to the obscene disparities in wealth and opportunities in the north, and the evident failure to address them (which the almajirai exemplify). Both northerners and southerners, Muslims and Christians alike, frame the almajirai as the product of a 'culture of poverty'. Often the almajiri system is criticised as Hausa cultural accretion to Islam, and it is pointed out that Islam permits begging only in acute emergencies (e.g. Bambale 2007). The almajirai, conversely, are described as preferring begging to 'work', and learning 'laziness' and a 'culture of dependence' (e.g. Aluaigba 2009; Ndagi 2012). By conceiving of begging as a cultural evil, its basis in material circumstances can be ignored.

The poor rural constituencies opting for the almajiri system are described as 'backward' in their aspirations and unable to appreciate the benefits of modern education, 
enrolling their wards instead in a system out of tune with the 'exigencies of modern times' (Saidu 2010). They are accused of producing more children than they can take care of, to then deliver them to a life of misery as 'street children' ("The Almajiri Education Foundation" 2012) and quasi-orphans (e.g. COCFOCAN), 'forsaken by their parents' (Shehu 2010) and 'totally neglected' ("NGO Works to Improve Muslim Education" 2007). Bala Muhammad, then head of a Kano State directorate created to promote morals and good behaviour, for instance, chides 'parents who have more children than they can afford and see Koranic schools as a means to rid themselves of the extra burden' (Abubakar 2009). Sule-Kano, academic at Usmanu Danfodiyo University Sokoto, writes that under conditions of poverty, 'Almajirci [the practice of living as almajiri]... became a perfect excuse to some parents to reduce the burden of rearing children' $(2008,6)$. Aishatu Jibrin Dukku, Nigeria's Minister of State for Education at that time, claims that the almajirai's parents are 'so insensitive to the welfare of their children that they dispatch them to unknown places to take care of themselves' ("Nigeria's 10mn Child Beggars" 2009).

While it is acknowledged that many of those opting for the almajiri system do so out of poverty, few attempts are made to understand the structural causes of their poverty, or the ways in which they make sense of the constraints they are subjected to. Buzzwords such as 'parental neglect' and 'ignorance' dominate the discussion rather than the acknowledgement that those sending their children as almajirai may make an informed choice in a context offering few alternatives. Ultimately, the burden of blame is put on the poor. Yet, this is inherently dangerous as it may give rise - and legitimacy - to government policies that penalise the poor rather than address their grievances (cf. Wacquant 2003). Since the escalation of violence associated with Boko Haram, there have been increasingly frequent calls for restrictions on the almajirai's mobility and even an outright ban on the system. The Northern Traditional Rulers' Council for example suggests such a ban (Folaranmi 2011). Plateau State outlawed street begging by school-aged children in 2009, and on federal level a similar law is in the legislative pipeline.

\section{Coping strategies of the poor}

\subsection{Escaping difficult conditions and accessing opportunities absent at home}

Almajiri education today promises neither access to political power nor to high social status. Its former economic viability has largely been undermined and its religious merit come under attack. Those participating in it may soon find themselves criminalised - so why do people still opt for the system, one may wonder? Hopes for better opportunities for oneself (in the case of older students) or one's wards (in the case of parents and guardians) as well as the hope to overcome problems at home underpin the migration of children and youths/young adults to urban areas as almajirai. Structural factors such as the decline of the rural economy and the population more than quadrupling since 1950 (UN 2010) constrain the opportunities available to poor peasant households in rural areas. This has contributed to perpetuate both poverty and educational disadvantage.

The appeal of, and consequently demand for, modern education is low as its quality and returns in terms of employment compare poorly to its costs, particularly in rural areas. Low levels of education spending, high pupil/classroom ratios, and low teacher qualification account for poor learning outcomes (e.g. Ministry of Education 2008; Johnson 2010). While basic education is officially free, in reality it implies recurrent expenses: for text books and writing materials, uniforms, charges for the rehabilitation of decaying school facilities, levies to buy chalk, brooms, report cards, etc. Post-primary education in particular has its price starting with the bribe sometimes required to secure one of the limited places - and often 
requires students to commute or board. Tomasevski (2005) argues that only education that doesn't imply opportunity costs - e.g. in the form of foregone income or benefit from children's work - can be considered truly free. The situation in much of Kano State is very far from this ideal, and modern education is inaccessible to many poor children.

It is a widely held tenet in Hausa society that every child should attend school; failing to enrol a child is tantamount to letting him 'go to waste' (lalace) (e.g. Last 2000). When modern education is inaccessible, the almajiri system affords an alternative avenue to 'save' both the child and one's face as responsible parent. ${ }^{\text {ii }}$ Also, moving to an urban area as almajiri may, for older youths with sufficient means and determination, be a strategy to acquire (belatedly) some modern knowledge: I met several Qur'anic students in their late teens and early twenties who attended adult literacy evening classes in Kano - an opportunity virtually absent in rural areas.

Divorce is frequent and easy to achieve in Hausaland. Estimates suggest that over $75 \%$ of marriages in Kano City are divorced (Uwais et al. 2009, 20). Many marriages end in divorce because husbands fail to take care of the basic subsistence needs of their families, or because of fights between or over co-wives. In the case of divorce, the need may arise to 'reaccommodate' children. Divorced mothers, who are expected to re-marry soon, can rarely move into new marriages with children from previous ones. Children left with fathers are at risk of suffering neglect, and abuse from stepmothers. High maternal mortality also renders children motherless ("Partnership for Transforming Health Systems" 2012). Girls may find themselves fostered out to relatives, or married off young. For boys, the almajiri system offers a way out under such constrained circumstances.

Gathering the resources to launch an adult career - i.e. to build a room for prospective bride(s) and children, and to marry - affords a real challenge to adolescent boys and young men in an eroding rural economy where opportunities to earn cash income are scarce. Seasonal or permanent migration to the cities, which offer petty income opportunities as street vendors and odd-job men, promises redress. Migration, especially during the agriculturally unproductive dry season, is indeed a common strategy of Sahelian peasant households to reduce their subsistence burden and allows boys to acquire livelihood skills appropriate to the ecology of the region (Mortimore 1998; Mustapha and Meagher 1992).

Families or caregivers make sense of their decisions to send their children to live as almajirai in the urban centres with reference not only to their high regard for Qur'anic learning (in a context where religious subjects are inadequately integrated into modern school curricula) but also mindful of the educational value of a certain degree of hardship for the social and moral training of their children (e.g. Last 2000). The next section engages with the ways in which the almajirai appropriate such narratives about the educational value of hardship for their own purposes.

\subsection{Escaping shame}

In a very status-conscious environment like Hausa society (Last 2000, 382), migrating means to remove oneself, at least to some extent and for some time, from one's assigned position within the status hierarchy. This does not mean that migrants turn into 'loose molecules' (Kaplan 1994, 46) as many migrate within networks that connect them to their home localities and through which social control is, to some degree, maintained. However, coming to a noisy, crowded, and heavily populated city like Kano also means instances of anonymity, unstable hierarchies made in the instant, and the proliferation of novel strategies to signal status.

For the almajirai, migrating entails both risks and opportunities in terms of social standing. For once, they can to some extent conceal individual life histories. These often engender shame as they are shaped by a lack of support from (supposedly responsible) social 
elders as a consequence of poverty, divorce or death. Life in the city affords anonymity, and enrolment as almajiri doesn't require an explanation in terms of personal circumstance: after all, searching for religiously enjoined knowledge is not an endeavour in need of justification.

Moreover, as has been pointed out above, hardship is part and parcel of the educational ideology of the almajiri system. Children in Hausa society are seen as 'beings who require disciplining in order to become human', Last argues. Undisciplined children are perceived as animal-like as 'they simply sleep, eat and drink' (2000,374). Without 'external shaping' in the form of discipline and physical hardship 'a child is scarcely human, and certainly not a proper Muslim' (376; see Schildkrout [1978] 2002). Strictness and physical punishment are perceived as necessary and even beneficial for a child and his learning, and while it is recognised that parents are reluctant to exert much harshness, this is perceived as weakness. Malam Ahmadu for example, Qur'anic teacher at Sabuwar Kofa where I lived during my stays in Kano City, explained his decision to teach almajirai rather than students from the neighbourhood to me with his experience that close-by parents could not help but interfere in the teaching. Rather than blaming them, he took this to be a structural problem to be solved by sending children away.

Cultural norms that ascribe educative value to hardship provide a vocabulary with which almajirai can justify their deprived conditions, eschewing the familiar narratives of poverty and parental neglect. In this way, being an almajiri can attenuate the shame associated with poverty. After all haven't the almajirai proven outstanding religious dedication by forgoing the (presumed) comforts of home for the sake of knowledge? This is the narrative the almajirai I got to know well were working towards. During script writing, for example, the boys involved in the film project invoked any number of social, cultural, and religious arguments to justify enrolment as almajiri:

- At home, he [a child] becomes stubborn, quarrelsome with other children and disrespectful towards elders. If he's told to go to school, he doesn't go. He just goes for a stroll, annoying the people in the neighbourhood.

- Some are worried about the kind of kids their children associate with. That is why they decide to take them to school. Because if they'd leave them at home, they may become spoiled, but if they take them to school someone is looking after them because it's the malam's [Qur'anic teacher] work to look after them.

- Parents want their children to get to know their religion, and know people, and know how to live together with people.

When the script advisor, a professional from the Kano film industry, suggested that destitution was indeed a factor underpinning the enrolment of children as almajirai, the boys nodded approval. Yet, they did not hesitate for a moment to take him up on his suggestion to disregard this aspect of the system in their script. On other occasions, the almajirai outright refuted explanations invoking poverty or difficult conditions at home (e.g. parental divorce or death) as reasons for almajiri enrolment. Nasiru ${ }^{\text {iii }}$ (15 years) for instance contended that

... especially now that there is boko [modern school], if you come for almajirci, some people think it's because you don't have food in your house, that's why you come out to beg. But it's not like that; it's because you're searching for knowledge.

Habibu (15 years) refutes the claim of parental neglect, suggesting that

people bring their children to Qur'anic school not because they hate them, but because they want them to have the knowledge. 
I was surprised to find that even schoolmates who had been enrolled in the same Qur'anic school for years and shared their daily routines with each other as friends, knew very little about each other in terms of family background. Bashir for instance, did not know that Khalidu was orphaned and had become an almajiri as a consequence of parental death. They had been schoolmates for over two years and appeared to be quite close friends.

My informants of course did not necessarily make an exemption for me from their strategies of concealment and often it was only after careful probing, or engaging other family members in the conversation, that I found out about the underlying material circumstances of a child's first enrolment as almajiri. The young people themselves often prioritised religious and cultural values over material constraints when explaining their careers as almajirai.

Idris, for example, in his early twenties, had enrolled as almajiri after only one month of secondary school. When I asked about the school change, he explained it in terms of the importance of religious knowledge in this world and the hereafter. Only when I probed whether any key event triggered his drop-out, he revealed that his father had died at the time.

Isiyaku, in his early twenties and returned almajiri, whom I interviewed in the presence of his mother, explained to me that he dropped out of modern education to become an almajiri whereas his junior brother persisted through modern education as the latter had more of the kind of intelligence required for modern knowledge. His mother then chipped in explaining that Isiyaku had to drop out of modern education because his father was very ill at the time and the household financially strained.

I do not mean to imply that people don't mean what they say when they stress the importance of religious knowledge, or that almajiri enrolments are necessarily caused by acute household emergencies. Rather, my point here is that the almajiri system and its ideology can act as a way to save face and allow people to maintain a sense of dignity and purpose in difficult circumstances.

\subsection{New vulnerabilities}

At the same time, however, the almajirai as newcomers and strangers (as opposed to the 'yan gari, the 'children of the town') are vulnerable to abuses they wouldn't be exposed to back home. Being away from home may allow them to cover up their social elders' failure to take appropriate care of them, and thus to evade the associated shame. Yet, in a society in which individuals derive their social standing from the people they 'belong' to (be it family members or patrons), being unable to display such belonging means to be vulnerable and defenceless. The term gata connotes a person whom you can legitimately expect to stand up as well as provide materially for you. The almajirai I conducted my research with often explained the abuses they suffered with reference to the apparent absence of such guardians or protectors. During the script writing process for the film, for instance, the participating boys noted that almajirai are often mistreated because

\footnotetext{
people see he [the almajiri] doesn't have a guardian/protector (gata), and if they mistreat him, nothing will happen to them. And the almajirai's teachers want to live in peace with the people from town. That's why even if almajirai have been mistreated, they'll tell them to have patience.
}

The almajirai felt emasculated particularly in their interactions with other young people in the neighbourhoods of their schools, including their employers' children. These would often mock and bully almajirai with impunity. I would not go so far as to suggest it is considered legitimate to treat someone badly for lack of gata. But as an explanation for bad and heedless treatment it makes immediate sense to people. Command over and claims to other people's respect, I would venture, inhere not in the individual, but in the social 
hierarchy she or he belongs to. To fend off assaults on their dignity, the almajirai participating in the film project declared and asserted they too had their supporters and protectors rather than demanding that everyone should be treated with respect and dignity irrespective of whether or not he has gata. Buhari (ca. 20 years) for instance, part of the film production crew, proclaims in the end credits where the almajirai spell out their messages to the public:

I want those people who abuse almajirai to understand that they also have people who care about them.

There are other sources of vulnerability for almajirai apart from their difficulties in displaying 'belonging'. Unlike in a village context where nearly everyone knows nearly everyone's family background, in an urban environment anonymity characterises many encounters. Displays of 'belonging' have thus been complemented with novel ways of signalling one's status. Demonstrations of wealth are of course a popular default option for those wishing to make claims to high rank: posh cars are the preserve of the rich; flashy mobile phones and glamorous clothes belong to the symbolic repertoire also of the somewhat less lavishly endowed. Finally, shows of one's mastery of prestigious and hard-to-attain forms of knowledge - e.g. conversing in English (preferably in the presence of Hausa-only speakers!), reciting the Qur'an in the qira' $a$ of Hafs (rather than the 'folk' Warsh version), or at least greeting ('Assalamu alaikum wa rahmatullahi wa barakatuh') with an Arabic accent work effectively to create instantaneous hierarchies. Unfortunately, almajirai mostly lack the economic and cultural capital required to participate in such new styles of differentiation. For the most part they don't command the financial resources for displays of wealth, and 'modern' forms of knowledge are difficult to acquire, especially for those attending only Qur'anic school. All together, there is little to protect the almajirai from lingering at the bottom of the status hierarchy and thus becoming easy prey for those searching for scapegoats. Being blamed for incidents in their neighbourhoods is an experience shared by many almajirai:

\footnotetext{
Some offences, it's not an almajiri who committed them; it's the people/kids from town ('yan gari). But they'll just say an almajiri committed it, if there's a school close-by, they'll just go and tell the malam (Qur'anic teacher): look what your almajirai did, whereas it wasn't them who did it. The people from the neighbourhood don't see their own children's faults. (Auwalu, late teens, during script writing)
}

The almajirai I conducted my research with were not only aware of the attitudes of the public towards them but felt many of the accusations were unwarranted. The youths involved in the film project for instance were upset about having to serve as scapegoat. Without someone answering for them close-by, they felt they had become fair game for unfair accusations. How upset the almajirai participating in the film project were about being denied respect becomes apparent in the messages to the public they included in the end credits of the film. Six of the nine participants voice respect as their biggest worry and call for a more sympathetic view on almajirai, for example:

- I want those who think almajirai are bad people to know that they aren't. Either speak good about us or keep quiet. (Kabiru)

- I call upon you to stop accusing almajirai of things they didn't do. Please inquire first before you just accuse the almajirai. (Naziru)

- I call upon those people who insult us, who think we are useless, to stop as of today, for the sake of God. (Auwalu) 
As a matter of fact, the truth content of accusations against the almajirai is secondary to my argument that it is easy and, for many, convenient to resort to scapegoating almajirai. As long as the almajirai can be blamed for petty incidents in their neighbourhoods, there will be no need for potentially tedious confrontations with the parents of other youngsters. As long as the inadequacies of the almajiri system serve to 'explain' the Boko Haram related violence discussed earlier, it is possible to put more complicated questions about poverty, inequality, and alienation on the back burner. This brings me back to the argument made at the beginning of this paper that in an increasingly individualistic social environment, the burden of blame is easily put on individuals, especially the poor, rather than on the social ills constraining their room for manoeuvre.

\section{Conclusion}

Mobility is a contradictory resource for the almajirai. They can draw on it to seize educational and income opportunities missing at home, or to escape from situations in which there is no other way forward. Modern education in rural areas is both low in quality and costly for poor households, and its returns in terms of future employment are uncertain. The almajiri system offers an alternative educational avenue. An eroding agricultural economy offers few if any cash income opportunities for young people. Migration to the city promises redress as young people can get by as household helps, odd-job men or street vendors. High rates of divorce and parental death further precipitate children to leave home. Contrary to the widespread idea of 'education' as a preparatory phase whose fruits are to be reaped in the future, the almajiri system offers solutions for the challenges of daily subsistence in the here and now. However, whether it entails future benefits for its students is uncertain.

Migration grants the almajirai access to self-conceptions as migrants in search of sacred knowledge. Yet, such dignified notions compete with their negative mirror image. Often, the almajirai are portrayed as the product of parental backwardness and neglect, and as such prone to become nuisances, troublemakers and - against the backdrop of escalating Boko Haram related violence - terrorist cannon fodder. Surprisingly, the notions espoused by the almajirai and by their opponents have more in common than one would prima facie expect:

I have argued that as a consequence of economic and societal change in Nigeria, the poor are often blamed for their squalor as economic success is considered a result of individual industry and merit rather than one's position within larger social determinants of privilege and opportunity. Paradoxically, in their attempts to defend their sense of self and self-worth, the almajirai play into the hands of such logics that delegitimise them. By embracing self-conceptions as devoted searchers for sacred knowledge, ironically, they become more vulnerable. They adopt a trope that prioritises the cultural and religious aspects of the almajiri system over its material bases. Thereby, they may unwittingly buttress culturalist explanations, which, changed into the negative, evoke 'backward' educational aspirations and neglectful and ignorant parents. Such culturalist explanations, in turn, invite punitive responses from governments. The proposed ban on the almajiri system is a case in point.

It is easily comprehensible that the almajirai adopt the trope of devout migratory scholars given the daily assaults on their dignity and identity that they have to fend off. It is, however, tragic in that it keeps off the table a debate about the structural causes of the poverty afflicting the constituencies that opt for the almajiri system. Such a debate would, however, be important in order to achieve a change for the better for the almajirai and their families.

In conclusion, it is important to be mindful of the ways in which discourses that stigmatise poor young migrants may develop a dynamic of their own. Shame has been argued to be at the 'irreducible absolutist core' of poverty across cultures (e.g. Sen 1983, 159), and 
growing inequality is one of the biggest challenges of our time. Young migrants' movements are often linked to socioeconomic disparities between 'home' and 'host' regions or households, and stigma is a widely shared experience. Given this context, it is particularly important to better understand their struggles for dignity and (self-) respect. In order to defend their sense of self, young migrants may embrace self-conceptions which downplay the role of structural constraints in their lives. They may salvage their sense of purpose by portraying themselves as wilful and independent agents, thereby risking that others accuse them of a 'culture of poverty'. This paper has shown how important it is to bring to the fore the role that stigma plays for how poor young migrants construct their notions of self.

\section{Acknowledgements}

I thank the people in Kano and Albasu for hosting me and for sharing their lives so generously with me. I am grateful to my supervisors Dr Laura Camfield and Dr Abdul Raufu Mustapha for their guidance and support. Financial support from the German Academic Exchange Foundation (DAAD Deutscher Akademischer Austauschdienst), the German National Academic Foundation (Studienstiftung des deutschen Volkes), the Green Templeton College travel fund, the QEH travel fund, and the Gurdev Kaur Bhagrath Memorial Research Fund is gratefully acknowledged.

i Living in relative poverty is defined as living on $2 / 3$ or less of mean per capita expenditure.

ii Qur'anic/Islamiyya schools are of course available also in rural areas. For the reasoning that makes enrolment away from home appear more appropriate, see section 3.2..

iii I changed the names of informants where I felt it necessary to protect their identity. Where informants were comfortable with statements being publicised in their name and where I considered this safe for them, I left names unchanged. 
References:

Abubakar, Aminu. 2009. "Nigeria Struggles to Curb Rise in Child Beggars." Weekly Trust, November 21.

Adams, Mary. 2009. "Stories of Fracture and Claim for Belonging: Young Migrants' Narratives of Arrival in Britain." Children's Geographies 7 (2): 159-171.

Aigbokhan, Ben E. 2008. Growth, Inequality and Poverty in Nigeria. Addis Ababa, Ethiopia: Economic Commission for Africa.

Aluaigba, Moses T. 2009. "Circumventing or Superimposing Poverty on the African Child? The Almajiri Syndrome in Northern Nigeria." Childhood in Africa 1 (1): $1-37$.

Bagaji, Ali S Yusufu, Moses Shaibu Etila, Elijah E Ogbadu, and Garba Sule. 2012. "Boko Haram and the Recurring Bomb Attacks in Nigeria: Attempt to Impose." Cross-Cultural Communication 8 (1): 33-41.

Bambale, Abdu J. 2007. "Almajiranchi and the Problem of Begging in Kano State: The Role of Shekarau Administration (2003-2007)." 7th BEN Africa Annual Conference.

http://www.benafrica.org/downloads/bambale_begging_in_kano.pdf.

Beazley, Harriot. 2003. "Voices from the Margins: Street Children's Subcultures in Indonesia.” Children's Geographies 1 (2): 181-200.

COCFOCAN (Coalition of Community Based Organizations Focused on Child Almajiri in Nigeria). "The Child-Almajiri". Kano, Nigeria: Coalition of Community Based Organizations Focused on Child Almajiri in Nigeria.

Cresswell, Tim. 2010. "Mobilities I: Catching Up." Progress in Human Geography 35 (4): 550-558.

Crivello, Gina. 2009. “Becoming Somebody”: Youth Transitions Through Education and Migration - Evidence from Young Lives, Peru. Working Paper No. 43. Oxford: Young Lives.

Folaranmi, Femi Y. 2011. "Fallout of Boko Haram Bombings: Emirs Spit Fire." Sun News Online, November 19.

Freeman, Dena, ed. 2012. Pentecostalism and Development: Churches, NGOs and Social Change in Africa. Basingstoke: Palgrave Macmillan.

Gough, Katherine V. 2008. "“Moving Around': The Social and Spatial Mobility of Youth in Lusaka." Geografiska Annaler: Series B, Human Geography 90 (3): 243-255.

Hannam, Kevin, Mimi Sheller, and John Urry. 2006. "Editorial: Mobilities, Immobilities and Moorings." Mobilities 1 (1): 1-22.

Hansen, Karen Tranberg. 2005. "Getting Stuck in the Compound: Some Odds Against Social Adulthood in Lusaka, Zambia." Africa Today 51 (4): 3-16.

Ibrahim, Jibrin, and David Ehrhardt. 2012. "Christians and Christianity in Northern Nigeria." Paper presented at the conference 'Interfaith Relations in Northern Nigeria: From Research to Policy and Practice', Abuja, Nigeria, 1-2 August 2012.

Jacquemin, Mélanie Y. 2004. "Children's Domestic Work in Abudjan, Côte d'Ivoire.” Childhood 11 (3): 383-397.

Johnson, David. 2010. An Assessment of the Professional Working Knowledge of Teachers in Nigeria: Implications for Teacher Development, Policy and Implementation. Kano, Nigeria: Education Sector Support Programme in Nigeria. 
Kane, Ousmane. 2003. Muslim Modernity in Postcolonial Nigeria: a Study of the Society for the Removal of Innovation and Reinstatement of Tradition. Boston, MA: Brill.

Kaplan, Robert D. 1994. "The Coming Anarchy. How Scarcity, Crime, Overpopulation, Tribalism, and Disease Are Rapidly Destroying the Social Fabric of Our Planet." Atlantic Monthly 273 (2): 44-76.

Katz, Cindi. 2004. Growing up Global: Economic Restructuring and Children's Everyday Lives. Minneapolis, Minn: University of Minnesota Press.

Langevang, Thilde, and Katherine V. Gough. 2009. "Surviving Through Movement:

The Mobility of Urban Youth in Ghana." Social \& Cultural Geography 10 (7): 741-756.

Last, Murray. 1988. "Charisma and Medicine in Northern Nigeria." In Charisma and Brotherhood in African Islam, edited by D Cruise O'Brien and C Coulon, 116131. Harlow: Longman.

Last, Murray. 1993. "The Traditional Muslim Intellectual in Hausaland: The Background." In African Historiography, edited by Toyin Falola and JF Ade Ajayi, 116-131. Harlow: Longman.

Last, Murray. 2000. "Children and the Experience of Violence: Contrasting Cultures of Punishment in Northern Nigeria." Africa: Journal of the International African Institute 70 (3): 359-393.

Loimeier, Roman. 1997. "Islamic Reform and Political Change: The Example of Abubakar Gumi and the 'Yan Izala Movement in Nigeria." In African Islam and Islam in Africa: Encounters Between Sufis and Islamists, edited by David Westerlund and Eva Evers Rosander, 286-307. Athens, Ohio: Ohio University Press.

Lubeck, Paul M. 1985. "Islamic Protest Under Semi-Industrial Capitalism: 'Yan Tatsine Explained." Africa: Journal of the International African Institute 55 (4): 369-389.

Mann, Gillian. 2012. "Beyond War: 'suffering' Among Displaced Congolese Children in Dar Es Salaam." Development in Practice 22 (4): 448-459.

Ministry of Education. 2008. Educational Sector Analysis. Kano, Nigeria.

Mortimore, Michael. 1998. Roots in the African Dust. Cambridge: Cambridge University Press.

Mustapha, Abdul Raufu, and Kate Meagher. 1992. "Stress, Adaptation, and Resilience in Rural Kano." Capitalism, Nature, Socialism 5 (2): 107-117.

Ndagi, M U. 2012. “"Plaiting Louse-infested Hair' (II).” Weekly Trust, May 5.

"NGO Works to Improve Muslim Education in Nigeria." 2007. VOA News, November 28.

"Nigeria's 10mn Child Beggars." 2009. Nigerian Curiosity. http://www.nigeriancuriosity.com/2009/12/nigerias-10mn-child-beggars.html.

Ogunrotifa, AB. 2013. "Class Theory of Terrorism: A Study of Boko Haram Insurgency in Nigeria." Research on Humanities and Social Sciences 3 (1): 27-60.

Onuoha, Freedom C. 2011. "The Audacity of the Boko Haram: Background, Analysis and Emerging Trend." Security Journal 25 (2): 134-151.

Paden, John N. 1973. Religion and Political Culture in Kano. Berkeley: University of California Press.

"Partnership for Transforming Health Systems. Overview." 2012. Paths2. Accessed April

http://paths2nigeria.org/index.php?option=com_content\&view=article\&id=128 $\&$ Itemid $=109$. 
Porter, Gina, Kate Hampshire, Albert Abane, Kobina Esia-donkoh, Regina Obilie Amoako-sakyi, Samuel Agblorti, and Samuel Asiedu Owusu. 2013. "Mobility, Education and Livelihood Trajectories for Young People in Rural Ghana: a Gender Perspective." Children's Geographies 9 (3-4): 395-410.

Punch, S. 2007. "Negotiating Migrant Identities: Young People in Bolivia and Argentina." Children's Geographies 5 (1): 95-112.

Saidu, Khadijat. 2010. "Dislodging Almajiris' Bowls with Skills." The Nation, January 11 .

Schildkrout, Enid. [1978] 2002. "Age and Gender in Hausa Society: Socio-economic Roles of Children in Urban Kano." Childhood 9 (3): 342-368.

Sen, Amartya. 1983. "Poor, relatively speaking." Oxford Economic Papers 35: 153-69.

Shehu, Mustapha. 2010. "Almajiri Bill: The Masochism of Integration." Weekly Trust, January 1.

Sheller, Mimi, and John Urry. 2006. "The New Mobilities Paradigm.” Environment and Planning A 38 (2): 207-226.

Soyinka, Wole. 2012. "The Butchers Of Nigeria.” Newsweek Magazine, January 16.

Sule-Kano, Abdullahi. 2008. "Poverty and the Traditional Qur'anic School System in Northern Nigeria: The Politics of the Almajiri-phenomenon". Paper prepared for the Conference on Nigerian Youth and National Development, Centre for Democratic Research and Training, Mambayya House, Bayero University, Kano, Nigeria, 5-6 August 2008.

"The Almajiri Education Foundation." 2012. CONSS, Coalition of NGOs (nongovernmental Organisations) in Sokoto State. Accessed January 3. http://www.conss.net/almajiri.htm.

"The Popular Discourses of Salafi Radicalism and Salafi Counter-radicalism in Nigeria:

A Case Study of Boko Haram." (2012).Journal of Religion in Africa, 42, 118-144.

Thorsen, Dorte. 2012. Child Domestic Workers. Evidence from West and Central Africa. Dakar-Yoff: UNICEF.

Tilde, Aliyu U. 2009. "The Future of the Almajiri (2)." Gamji. http://www.gamji.com/tilde/tilde106.htm.

Tomasevski, Katarina. 2005. "Not Education for All, Only for Those Who Can Pay: The World Bank's Model for Financing Primary Education." Law, Social Justice \& Global Development Journal 9 (1): 1-19.

UBEC (Universal Basic Education Commission). 2010. National Framework for the Development and Integration of Almajiri Education into UBE Programme. Abuja, Nigeria.

Umar, Muhammad S. 2001. "Education and Islamic Trends in Northern Nigeria: 1970s1990s.” Africa Today 48 (2): 127-150.

UN. 2010. World Population Prospects: The 2008 Revision. http://esa.un.org/unpp.

UNDP. 2009. Human Development Report 2009. Overcoming Barriers: Human Mobility and Development.

Uwais, Maryam, Deborah Mansfield, Tauhida I Bamali and Clare Manuel. (2009). Improving the Legal Investment Climate for Women in Africa NIGERIA.

van Blerk, Lorraine. 2005. "Negotiating Spatial Identities: Mobile Perspectives on Street Life in Uganda." Children's Geographies 3 (1): 5-21.

Wacquant, L. 2003. "Toward a Dictatorship over the Poor? Notes on the Penalization of Poverty in Brazil." Punishment \& Society 5 (2): 197-205.

Ya'u, Yunusa Zakari. 2000. "The Youth, Economic Crisis and Identity Transformation: The Case of the Yandaba in Kano." In Identity Transformation and Identity Politics Under Structural Adjustment in Nigeria, edited by Attahiru Jega, 161- 
180. Uppsala \& Kano: Nordiska Afrikainstitutet, Uppsala in collaboration with The Centre for Research and Documentation, Kano. 